Jurnal Ekonomi Pembangunan, 18 (2), 2017, 175-182

\title{
Factors Affecting Sustainability of Alternatives Livelihood in Coastal Community of Nembrala, East Nusa Tenggara: an Application of Micmac Method
}

\begin{tabular}{|c|}
\hline Chaterina Agusta Paulus ${ }^{1 *}$, Akhmad Fauzi \\
\end{tabular}

Received: June 2017 | Revised: November 2017 | Accepted: November 2017

\begin{abstract}
Coastal communities are known to prone to vulnerability arising from their nature of work. As they are mostly working as fishermen, natural hazards, isolation and climate variabilities are often constraining their ability to obtain sufficient income to support their livelihood. Hence, finding sustainable alternatives source of income is a sensible way to cope with such uncertainty and vulnerability. Achieving sustainable income, nevertheless, is challenging issue since it is affected by various factors from socio-economic as well as institutional perspectives. This paper is an attempt to assess the issue of alternative livelihood by identifying key variables affecting its sustainability. A MICMAC method was used and key variables from the analysis were then identified to support sustainable alternative livelihood in the communities. Lessons learned were also drawn from this study for policy makers and fisheries authorities in the regions.
\end{abstract}

Keywords: Sustainability, alternative livelihood, coastal communities, vulnerability, MICMAC. JEL Classification: Q01;Q55;q42

How to cite: Paulus, C., \& Fauzi, A. (2017). Factors Affecting Sustainability of alternatives livelihood in coastal community of Nembrala East Nusa Tenggara: An Application of MICMAC Method. Jurnal Ekonomi Pembangunan: Kajian Masalah Ekonomi dan Pembangunan, 18(2), 34-41. doi:https://doi. org/10.23917/jep.v18i2.4397

DOI: https://doi.org/10.23917/jep.v18i2.4397

\section{Introduction}

Coastal communities engaging in smallscale fishing activities, especially in developing countries play a greater in rural economy (Bene, 2006). The contribution of these communities is not only in the absorption of labor force but also in terms of livelihood in a broader sense (Barnes-Mauthe et al., 2013). Barnes-Mauthe et al. (2013) also shown that shown that small- scale fishing employs $87 \%$ of adult population in coastal areas and generates $82 \%$ of household incomes. It also provides $99 \%$ of animal protein for coastal people. Similarly, a comprehensive study by Kittinger et al. (2016) showed that small-scale fishing activities provide more than $7000 \mathrm{~kg}$ of seafood per year equal to more than 3000 meals worth more than US $\$ 78000$ per year. 


\section{Jurnal Ekonomi Pembangunan, 18 (2), 2017, 175-182}

Despite their importance, however, coastal communities are susceptible to any disturbances arising both from natural as well as anthropogenic sources (Ferrol-Schulte et al., 2015). Most coastal people are working as fishermen as the main source of income with very limited alternative source of livelihood. Disturbances from natural hazard, climate variabilities as well as economic shocks due to their isolation making them more vulnerable to fall into a poverty trap. Hence, developing alternatives livelihood is the only sensible way to cope with such vulnerability (Allison \& Ellis, 2001; Sievanen, 2014). Such a situation is faced by coastal communities of Nembrala village in Rote island, East Nusa Tenggara province.

Located in the southwest of Timor Island, Rote island in East Nusa Tenggara is one of the smallest islands in the southern part of Indonesia. The total land area of this island is only $1,280.5 \mathrm{~km}^{2}$ , which is much smaller compared to its sea area surrounding the island, which is $2,376 \mathrm{~km}^{2}$. With its comparative advantage on ocean resources, the Rote island should have been developed economically based on ocean resources such as fishing and tourism. Yet among 137 thousand people living in this island, more than $28 \%$ of its population is still living under poverty. This indicates that the natural resources of this island have not been used optimally. Characterized by small island, natural hazards, climate variability and isolation might be attributed to the poverty and non-optimal use of island's resources. Fishing as main source of occupation of the population is subject to vulnerabilities due to climate variabilities and natural hazards. This will have significant impacts on overall livelihoods of the communities. Therefore, in order to cope with income uncertainties derived from fishing, some alternatives livelihoods should be developed. Such alternative livelihoods should not only be affordable, but also should be sustainable. Local communities have developed two most commons alterative livelihood i.e, pig farming (livestock) and weaving. These alternatives livelihood are based on local resources and involve more people to work, and economically feasible (Paulus, 2016). This study aims to assess the issue of alternative livelihood by identifying key variables affecting its sustainability. Such findings will enable local authorities to develop alternative livelihood programs that are more sustainable at community level.

\section{Research Method}

Sustainability is of the key factors to ensure the long term alternative livelihood be uphold. Nevertheless, sustainability encompasses many dimensions such as economic, social, technological as well as institutional aspects. Identifying variables among those dimensions is quite challenging. In order to identify key sustainability variables, this study used an FGD technique involving 35 respondents selected purposively. The identified variables were then grouped into four categories i.e., economic, socio-cultural, infrastructure and Institution. A MICMAC (Matrix of Crossed Impact Multiplications Applied to a Classification) developed by Godet et al. (1999) and Godet (2006) were used to assess variables that influence the sustainability of alternative livelihood. MICMAC is part of a structural analysis whereby variables are mapped into influence and dependence components of the variables within a system. MICMAC has been suggested for sustainable analysis in various cases (Fauzi, 2017; Ahmed et al., 2009; Arozamena et al., 2012). MICMAC has strength in capturing the interaction among variables and identifying critical variables that can be used as driver for a system to work sustainably (Vetmeyer and Sahin, 2014). In our study, MICMAC is expected to identify key variables that support sustainable alternative livelihood in the coastal economic system. Hence results from MICMAC analysis could be used to design better and effective policies.

MICMAC uses three basic steps to be carried out as described in Godet and Roubelat (1996). These are: (1) Identifying the Elements 
(variables); (2) Describing the relationship between the variables, and (3) Identifying the key variables. Step 1 of MICMAC analysis in this study was carried out by identifying key variables of alternative livelihood from the FGD in the village of Nembrala, while step 2 and step 3 were carries out automatically once the data have been entered into the MICMAC computer program developed by Lipsor.

\section{Results and Discussion 3.1 Identifying elements}

From an FGD with local communities as well as relevant stakeholders, 21 elements or variables representing economic, social, technology and institutional dimensions were identified resulting in 21 x 21 element of Matrix. These 21 variables represent both communities and local authorities concern with regard to livelihood sustainability in the area. The number of variables (the size of variables) are unevenly distributed among sustainability dimension due to the fact that there is overlapping measurement among variables within each dimensions. For example, variable of social role could be included within institutional dimension but could also be grouped in social dimensions. Similarly, "system of maintenance" could be grouped in technological dimension but could also be grouped in environmental dimension. For the purpose of this analysis and based on agreement from focus group discussion, the 21 variables are grouped as listed in Table 1. These variable are then included in MICMAC analysis.

Each of these 21 elements were then evaluated in order to have $21 \mathrm{X} 21$ cross-impact matrix called MDI (Matrix of Direct Influence). This MDI matrix is listed in the following figure 1.

Table 1. Identified sustainability variables for alternative livelihoods

\begin{tabular}{|c|c|c|}
\hline Dimensions & Variables & Short label \\
\hline Economics & $\begin{array}{ll}\text { 1. } & \text { Access to market } \\
\text { 2. } & \text { Marketing chain } \\
\text { 3. } & \text { Contribution to local Revenue } \\
\text { 4. } & \text { Price of livestock } \\
\text { 5. } & \text { Feasibility }\end{array}$ & $\begin{array}{ll}\text { - } & \text { Aksespsr } \\
\text { - } & \text { Rantaipmsr } \\
\text { - } & \text { Pad } \\
\text { - } & \text { Harga } \\
\text { - } & \text { Layak }\end{array}$ \\
\hline Socio-cultural & $\begin{array}{ll}\text { 6. } & \text { Social role of livestock } \\
\text { 7. } & \text { Family participation } \\
\text { 8. } & \text { Empowerment } \\
\text { 9. } & \text { Number of farmers } \\
\text { 10. } & \text { Level of education }\end{array}$ & $\begin{array}{ll}\text { - } & \text { Peransos } \\
\text { - } & \text { Partisipas } \\
\text { - } & \text { Pemberdaya } \\
\text { - } & \text { Jmlhptrnk } \\
\text { - } & \text { Pddkn }\end{array}$ \\
\hline Environment & $\begin{array}{l}\text { 11. System of maintenance } \\
\text { 12. Waste } \\
\text { 13. Types of livestock } \\
\text { 14. Feeds availability } \\
\text { 15. Land availability }\end{array}$ & $\begin{array}{ll}\text { - } & \text { Pemelihara } \\
\text { - } & \text { limbah } \\
\text { - } & \text { jenistrnk } \\
\text { - } & \text { pakan } \\
\text { - } & \text { lahan }\end{array}$ \\
\hline Technology & $\begin{array}{l}\text { 16. Post-harvest indutsries } \\
\text { 17. Farming technology } \\
\text { 18. Livestock infrastructure }\end{array}$ & $\begin{array}{ll}\text { - } & \text { Indolah } \\
\text { - } & \text { Teknobudi } \\
\text { - } & \text { Infrstrk }\end{array}$ \\
\hline Institution & $\begin{array}{l}\text { 19. Number of farmer's group } \\
\text { 20. Extensions services } \\
\text { 21. Cooperative institution }\end{array}$ & $\begin{array}{ll}\text { - } & \text { Poknak } \\
\text { - } & \text { Pnlyhtnk } \\
\text { - } & \text { Kopnak } \\
\end{array}$ \\
\hline
\end{tabular}


Jurnal Ekonomi Pembangunan, 18 (2), 2017, 175-182

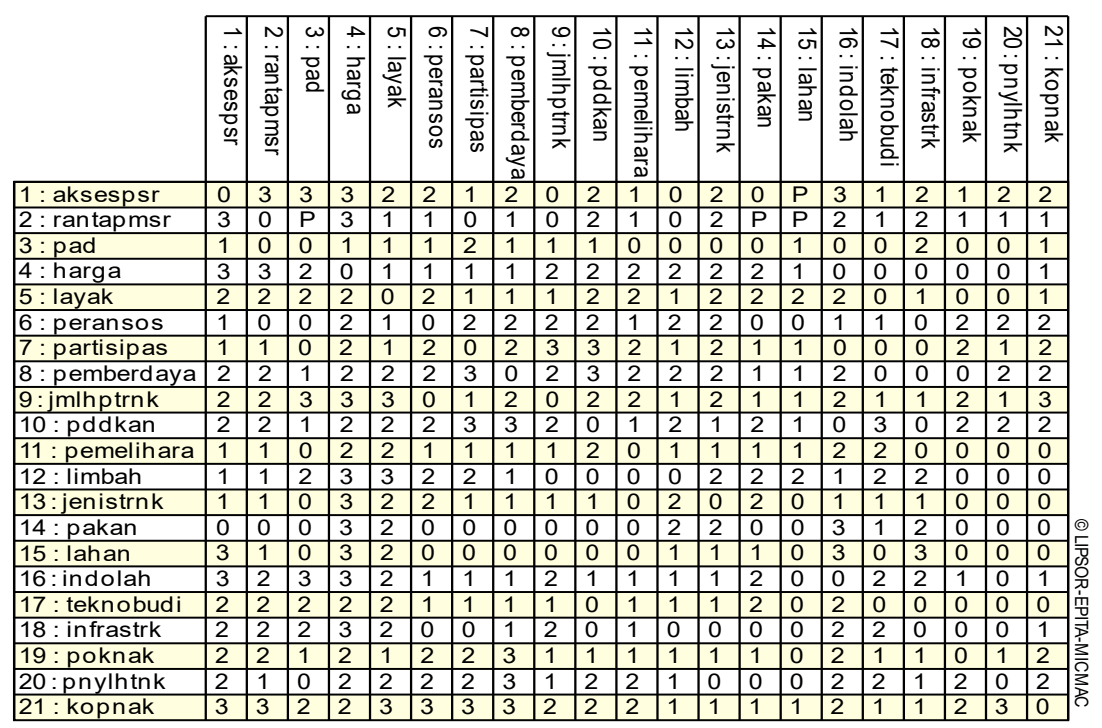

Figure 1. Matrix of Direct Influence (MDI)

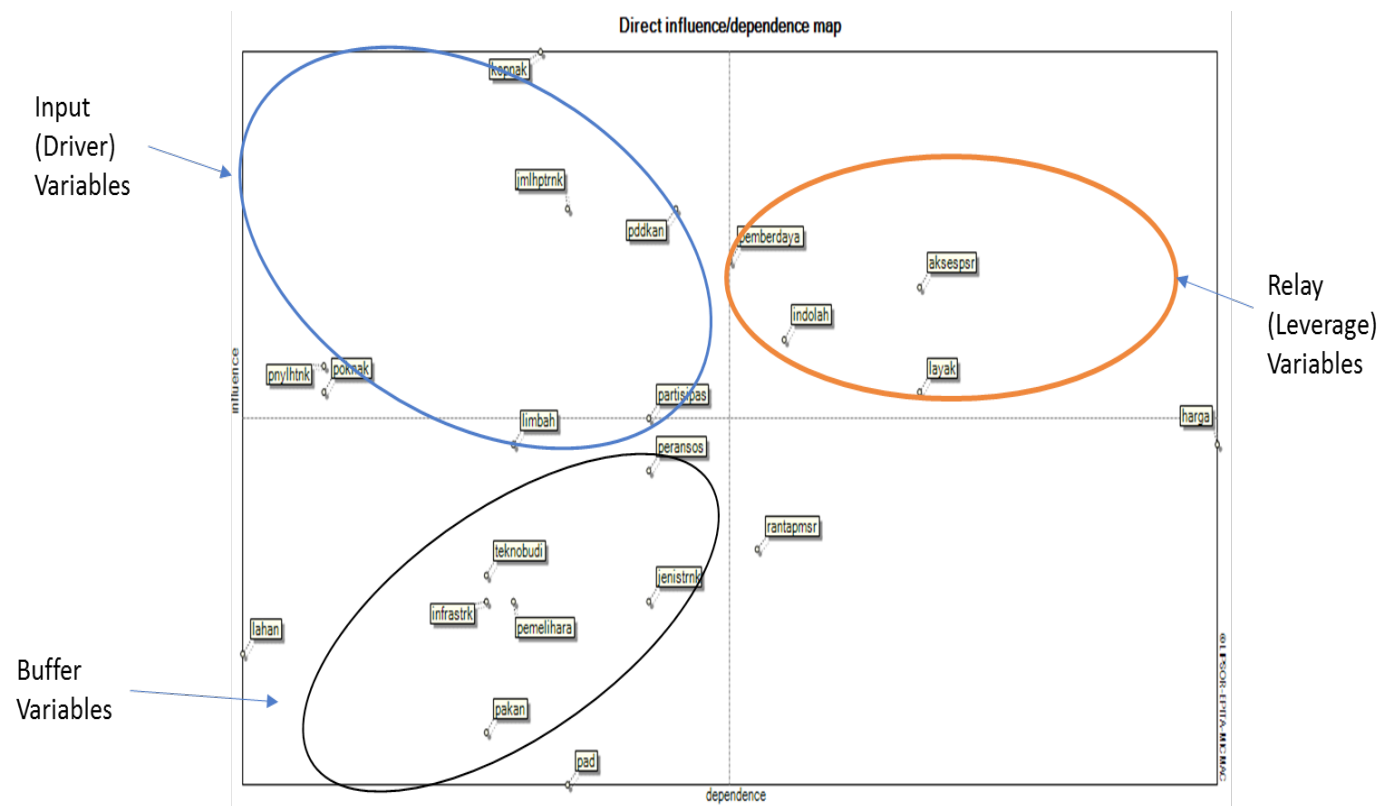

Figure 2. Influence-Dependence Map

\subsection{Relationship among variables}

Once MDI matrix has been identified and constructed, the next step in MICMAC analysis is to define the relationship among variables. There are two ways to describe this relationship.
The first one is by depicting the position of the variables through Influence-Dependence Map and the second is through inter-connecting among variables. The Influence-Dependence Map of these 21 variables is described in Figure 3. 


\section{Jurnal Ekonomi Pembangunan, 18 (2), 2017, 175-182}

As can be seen from Figure 2, most sociocultural and institutional variables are placed in the map as drivers or input variables. These variables are extension services, farmer's group, and number of farmers, level of education as well as level or participation. These variables serve as key driver in order that alternative livelihood to be sustainable. These results are in line with findings from Campbell et al. (2013) who found the importance of socio-economic and institutional coherence as key factors in smallscale fisheries management. In similar fashion, the results of this study are also supported by findings from Kittinger et al. (2015) who emphasize the importance of social and ecological factors for sustainable fisheries.

The second group of variables that also play a crucial role is relay variables. These variables are located in the upper right corner (north-east corner) of the map. Relay variables are those both influential as well as dependence. These variables could cause instability in the sustainability of alternative livelihood. Any slight changes in these variables could cause system of alternative livelihood to be unsustainable. Variables which have position as relay variables are mostly on economic and technological dimensions. These are access to market, feasibility of livestock, price of livestock, availability of post-harvest industries and empowerment of farmers. Access to market, for example, can be considered as relay variable (both influence and dependence) since access to market can influence any other aspects related to sustainability of alternative livelihood, especially, the pig farming and product resulted from traditional weaving. This variable, in the meantime, could also be considered as dependence variable since access to market depends on other variables such infrastructure, access to farmer's group, number of farmers and many others. Hence any changes in access to market could cause to level of sustainability in the community economic system of alternative livelihood.
Other group of variables are located in the south-west corner of the map. These variables are known as autonomous variables or "buffer variables". They have both characterized as little influence and dependence. Variables such land availability, local government revenue, feeds as well as maintenance have little influence on the sustainability of alternative livelihoods. This is due to that fact that these variables are not too specifically related to alternative livelihoods such as traditional weaving and pig farming. Farmers can get feeds from natural sources, for example. Similarly weavings do not require land as factor of inputs. Figure 3 describes the relationship among variables known as Direct Influence graph.

As can be seen from Figure 3, most variables from economic, technological and institutional aspects have strong influence on other variables. Access to market and price of livestock are strongly influenced by other economic variables, while empowerment and education as well as the presence of cooperative institution has strong influence on participation, technology and participation, respectively. The second degree of influence is shown by socio-cultural and environmental variables and weak influence is shown by variable land and type of livestock.

The relationship among variables from indirect influence perspectives can be seen in Figure 4. Compared with Figure 3, one can see that in terms of indirect influence, only the presence of cooperative institution has the strongest indirect influence to the market of livestock, while most variables are either relative strong and moderately strong indirect influence toward other variables. Figure 4 also indicates that land availability has the weakest indirect influence among other variables. This might be due to the fact that land is not an issue for the community as they can raise the pigs farming within their own backyard or let them free around the island. Similarly, traditional weaving activities can be carried out in their home without requires excessive land. 
Avalaible online at http://journals.ums.ac.id, Permalink/DOI: 10.23917/jep.v18i2.4397

Jurnal Ekonomi Pembangunan, 18 (2), 2017, 175-182

Direct influence graph

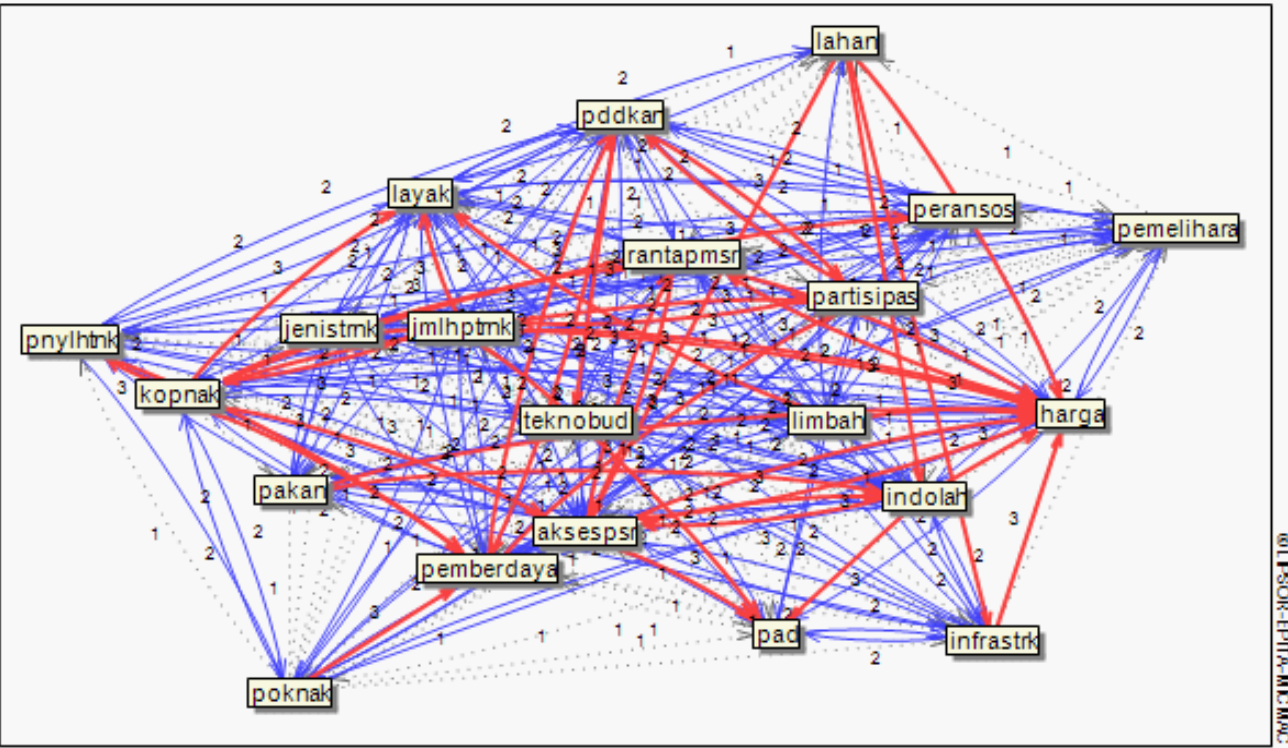

Weakest influences

- Weak influences

- Moderate influences

- Relatively strong influences

- Strongest influences

Figure 3. Direct influence graph for sustainable livelihood

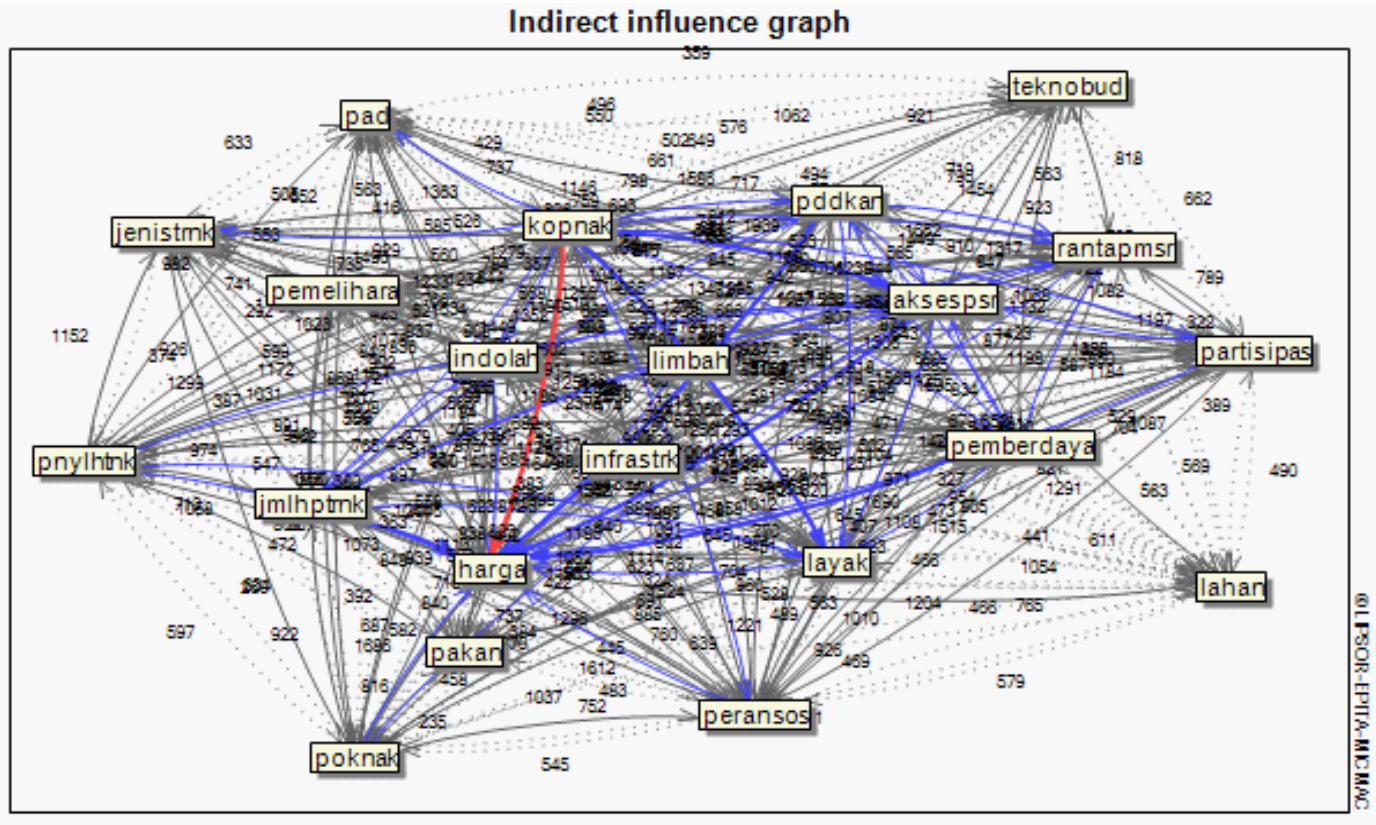

Weakest influences

Weak influences

- Moderate influences

- Relatively strong influences

- Strongest influences

Figure 4. Map of Indirect influence among variables 


\section{Jurnal Ekonomi Pembangunan, 18 (2), 2017, 175-182}

Figure 5 describes ranking comparison among variables according to their influences. As can be seen from Figure 5, there are some displacement among variable once the indirect influences have been calculated. For example, number of farmer (jmlhptrnk) and education have been displace each other. Previously number of farmer was in rank 2 under MDI matrix. This variable, however, is now rank 3 and has been displaced by level of education once the indirect influences have been take into account. A big displacement also occurs for variable social role whereby from MDI matrix it was in rank 13 now has moved to rank 10 .

Classify variables according to their influences

\begin{tabular}{|c|c|c|}
\hline Rank & Variable & Variable \\
\hline 1 & 21 - kopnak & 21 - kopnak \\
\hline 2 & 9 -jmlhptmk & 10 - pddkan \\
\hline 3 & 10 - pddkan & 9 - jmlhptmk \\
\hline 4 & 8 - pemberdaya & 8 - pemberdaya \\
\hline 5 & 1 - aksespsr & 1 - aksespsr \\
\hline 6 & 16 - indolah & 20 - pnylhtnk \\
\hline 7 & 20 - pnylhtnk & 19 - poknak \\
\hline 8 & 5 - layak & 7 - partisipas \\
\hline 9 & 19 - poknak & 16 - indolah \\
\hline 10 & 7 -partisipas & 6 - peransos \\
\hline 11 & 4 - harga & 5 - layak \\
\hline 12 & 12 - limbah & 4 - harga \\
\hline 13 & 6 - peransos & 2 - rantapmsr \\
\hline 14 & 2 - rantapmsr & 12 - limbah \\
\hline 15 & 17 - teknobudi & 18 - infrastrk \\
\hline 16 & 11 - pemelihara & 11 - pemelihara \\
\hline 17 & 13 - jenistmk & 17 - teknobudi \\
\hline 18 & 18 - infrastrk & 13 - jenistmk \\
\hline 19 & 15 - lahan & 15 - lahan \\
\hline 20 & 14 - pakan & 3 -pad \\
\hline 21 & 3 - pad & 14 - pakan \\
\hline
\end{tabular}

Figure 5. Ranking comparison according to influences

The ranking comparison for according to the dependences is depicted in Figure 6. As shown in Figure 6 three economic indicators are consistent in the top three as dependence variables i.e price, access to market and feasibility. The variable of the presence of post-harvest for pig farming, however, has been displaced quite significantly from rank 4 under MDI matrix to rank 6 once the indirect influence has been calculated. This indicates that such a variable is not priority at this time. Education variable, however, has jumped from rank 7 as dependence variable into rank 5 under MII matrix. This indicates that there is significant role of education in the community which can be influenced by other factor in sustainable livelihood.

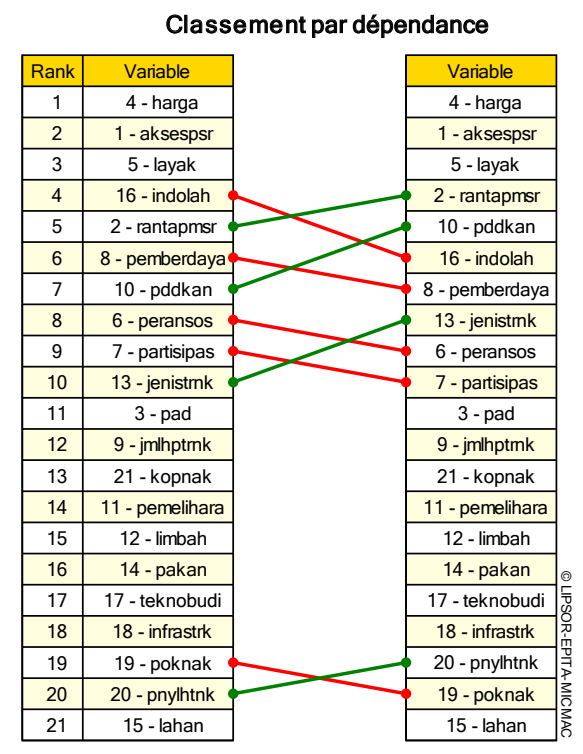

\section{Conclusions}

Providing alternative livelihood for coastal communities in Rote Island is an essential part to cope with uncertainty arising from external and internal shocks in the communities. Nevertheless, there is challenging issue to achieve sustainable level of alternative livelihood whereby various variables could influence the sustainability of the livelihood in the coastal economic system. This study is the first to assess factors affecting sustainability of coastal livelihood in Indonesia. It is also the first to employ MICMAC approach to address such issues. This paper has shown that by identifying key variables of sustainable livelihood, it helps policy makers to map which elements that could be used as input variables to deliver the policy to sustain the livelihood of the communities. It also helps to identify variables that could serve as leverage variables whereby 


\section{Jurnal Ekonomi Pembangunan, 18 (2), 2017, 175-182}

any changes in these variables could be detected earlier so that future anticipation and better planning could be designed. Results derived from this study could be used as lessons learned for all relevant stakeholders for better management of coastal area in general, and coastal livelihood in particular.

\section{Acknowledgement}

The Authors would like to thank Ministry of Research and Higher Education of funding this research through MP3EI scheme.

\section{References}

Ahmed, M.T., M. Saleh., A.F. Abdelkadir., A. Abdelrahim. 2009. El Maghara Scenario A Search for Sustainability and Equity: An Egyptian Case Study. Journal of Futures Studies, November 2009, 14(2): 55 - 90.

Allison E.H., Ellis, F., 2001. The livelihoods approach and management of small-scale fisheries. Marine Policy 25, no. 5, 377-388.

Arozamena, E.R., M.C.R. Puente., and A.D. Ibarbia. 2012. Influential Aspects Modeling for the Development of Sustainable Strategies in Industrial Case. Proceedings from the 16th International Congress on Project Engineering. Valencia. 2012.

Barnes-Mauthe, M., Oleson, K.L., Zafindrasilivonona, B., 2013. The total economic value of small-scale fisheries with a characterization of post-landing trends: an application in Madagascar with global relevance. Fisheries Research 147, 175-85.

Bene, C., 2006. Small-Scale Fisheries: Assessing their Contribution to Rural Livelihoods in Developing Countries. Food and Agriculture Organization of the United Nations, Rome, Italy.

Campbell, J., P. Townsley., E. Whittingham., J. Marsh. 2013. Key Factors supporting Small-scale coastal fisheries management. Synthesis Review. The Rockefeller Foundation.
Fauzi, A. 2017. Teknik Analisis Keberlanjutan. Manuskrip Buku. IPB. Bogor.

Ferrol-Schulte, D., Gorris, P., Baitoningsih, W., Adhuri, D.S., Ferse, S.C.A., 2015. Coastal livelihood vulnerability to marine resource degradation: a review of the Indonesian national coastal and marine policy framework. Marine Policy 52, 163-171.

Godet, M., Arcade, J., Meunier, F. \& Roubelat, F. 1999. Structural analysis with the MICMAC method and Actors' strategy with MACTOR method.

Godet, M. \& Roubelat, F. 1996. Creating the future: The use and misuse of scenarios. Long Range Planning, 29, 164-171.

Godet, M. 2006. Creating futures: scenario planning as a strategic management tool, London, Economica.

Kittinger, J.N., L.T. Teneva., H. Koike., K.A Stamaoulis., D.S. Kittinger., K.L.L. Olsen., E. Conklin., M. Gomes., B. Wilcox., A.M. Freidlander. 2015. From Reef to Table: Social and Ecological Factors Affecting Coral Reef Fisheries, Artisanal Seafood Supply chains, and seafood security. Plos One 10(8), 1-24.

Paulus, C.A. 2016. The Development of Sustainable Livelihoods for Peasant-Fisher in Rote Island East Nusa Tenggara.

Sievanen, L., 2014. How do small-scale fishers adapt to environmental variability? Lessons from Baja California, Sur, Mexico. Maritime Studies 13, 1-19.

Vetmeyer, J., and O. Sahin. 2014. Modelling climate change adaptation using cross-impact analysis: an approach for integrating qualitative and quantitative data. Proceeding of International Environmental Modelling and Software Society (iEMSs). San Diego, CA. USA. 